\title{
DITO E FEITO: A ESCRITA COMO LEITURA (E VICE-VERSA) NAS MEMÓRIAS DE PEDRO NAVA
}

Júlio de Souza Valle Neto Universidade Federal de São Paulo

julio.valle@unifesp.br

\begin{abstract}
RESUMO
O presente texto pretende examinar a inter-relação entre escrita e leitura nas Memórias de Pedro Nava. Para isso, serão analisados como ela se manifesta enquanto tema, em episódios selecionados, e enquanto prática, sobretudo considerando-se os paratextos editoriais de Baú de Ossos. Como conclusão, propõe-se que o texto articula os dois níveis, nisso consistindo um dos seus mais marcantes traços distintivos.
\end{abstract}

Palavras-chave: Pedro Nava. Literatura Brasileira. Citação. Paratextos.

\section{DICHO Y HECHO: LA ESCRITURA COMO LECTURA (Y VICEVERSA) EN LAS MEMORIAS DE PEDRO NAVA}

\section{RESUMEN}

Este texto pretende examinar la interrelación entre escritura y lectura en las Memorias de Pedro Nava. Para responder a este objetivo, hemos analizado episodios seleccionados que presentan esta interrelación como tema. Además, también hemos estudiado esta relación como práctica textual, contemplando sobre todo los paratextos editoriales de Baú de Ossos. Como conclusión, se propone que la obra articula los dos niveles de manera original, uno de sus aspectos distintivos más llamativos.

Palabras clave: Pedro Nava. Literatura brasileña. Citación. Paratextos.

\section{TO TELL, TO DO: READING AS WRITING (AND VICE VERSA) IN THE PEDRO NAVA'S MEMÓRIAS}

\begin{abstract}
This paper aims to discuss the interrelationship between writing and reading in Pedro Nava's Memórias. Therefore, we have selected three scenes of his work where this interrelationship appears as a topic. Furthermore, we have analyzed this connection as a textual practice, especially considering the editorial paratexts of Baú de Ossos. In conclusion, we have proposed that this work articulates these two different aspects, one of its most relevant features.
\end{abstract}

Keywords: Pedro Nava. Brazilian Literature. Citation. Paratexts.

\section{LE “DIRE” ET LE “FAIRE”: L'ÉCRITURE COMME LECTURE (ET VICE-VERSA)} DANS LES MÉMOIRES DE PEDRO NAVA

RÉSUMÉ 
Ce texte se propose d'examiner l'interrelation entre l'écriture et la lecture dans Mémoires de Pedro Nava. Pour cela, nous avons analysé comment cette interrelation apparaît comme un thème de l'œuvre, plus précisément, dans trois épisodes sélectionnés. De plus, nous étudions cette interrelation comme une pratique textuelle, en particulier dans les paratextes éditoriaux de Baú de Ossos. En conclusion, il est proposé que le texte articule ces deux aspects, l'une des caractéristiques les plus frappantes de l'œuvre de Pedro Nava.

Mots clés: Pedro Nava. Littérature brésilienne. Citation. Paratextes.

\section{INTRODUÇÃO}

As Memórias de Pedro Nava, desde Baú de Ossos (1972) até o sexto e último volume publicado integralmente, $O$ Círio-Perfeito (1984), constituem um marcante exemplo da relação entre escrita e leitura na criação literária. Essa interpenetração, sensível a ponto de Antoine Compagnon afirmar que, "na verdade, leitura e escrita são a mesma coisa" (1996, p. 29), fazse presente em vários níveis da obra do memorialista mineiro.

Um deles abarca os bastidores da escrita naviana. Flora Süssekind descreve, em "A Página do Lado" (1993), como o autor redigia o texto das Memórias, a partir de uma técnica aplicada do primeiro ao último volume. Munido de uma folha de papel sem pauta dobrada em duas partes, registrava à máquina, na face esquerda, a primeira versão do texto; na direita, citações, colagens e registros de toda sorte, dos verbais aos visuais, forneciam uma espécie de roteiro, destinado a dirigir a escrita e avivar a memória. A folha dobrada, contudo, pode ser considerada um estágio avançado dessa atividade prévia de pesquisa e leitura: antes dela, Nava registrava, em cadernos avulsos, notas sobre temas variados, incluindo impressões de leitura, que poderiam eventualmente inspirar a escrita; além disso, lançava em fichas específicas, descartadas na medida em que eram usadas (LE MOING, 1999, p. 128), informações de interesse para a redação do ciclo memorialístico. ${ }^{1}$

Contudo, para os limites deste artigo, o imbricamento entre leitura e escrita no ciclo memorialístico será tomado em outro nível. Afinal, tal interpenetração, evidente nos bastidores, também deixa marcas visíveis no texto de Nava: citações inumeráveis e sob variadas formas,

\footnotetext{
${ }^{1}$ Os Cadernos 1 e 2, publicados em 1999 em coedição da Ateliê Editorial e Editora Giordano, registram em facsímile as anotações do memorialista. As mesmas editoras incluem, ao final dos volumes das Memórias por elas reeditados, excertos dos originais de Nava em que é possível visualizar a prática descrita por Sussëkind. O Inventário do Arquivo Pedro Nava (2001), por fim, colige documentos de interesse nesse âmbito, como pastas com os originais, cartas e fichas diversas utilizadas para consulta. Eliane Vasconcelos, no texto que abre a publicação ("De Bissexto a Contumaz: o arquivo pessoal de Pedro Nava"), faz pertinentes considerações sobre o conjunto de materiais depositado na instituição. Sobre as fichas, a partir de um determinado ponto, seguindo a orientação do amigo Carlos Drummond de Andrade, Nava deixou de descartá-las, passando a arquivá-las para subsidiar estudos acadêmicos futuros (LE MOING, 1999, p. 128)
} 
muito especialmente epígrafes (a "citação por excelência"), nas palavras de Compagnon (1996, p. 35); paráfrases tendendo ora para a paródia, ora para o pastiche; menção a leituras diversas (de recreação, de estudo, de pesquisa), ora explícitas, ora implícitas, em momentos e circunstâncias diversos, da vida e do texto. O fenômeno parece mesmo amplo e generalizado e comporta, a nosso ver, um exame crítico, sob ângulo específico.

Para esse fim, o imbricamento entre leitura e escrita, nas Memórias de Pedro Nava, será dividido em dois grupos. No primeiro, interessará examinar, neste âmbito, o que o texto narra, ou seja, ocorrências nas quais essa interpenetração se faz presente enquanto tema (ou, mais precisamente, enquanto objeto de rememoração autobiográfica); no segundo, convirá deter-se naquilo que o texto $\mathrm{faz}$, a saber, no modo como essa inter-relação é articulada (ou mesmo, em casos específicos, dramatizada) em termos de composição formal. No primeiro caso, nos ocuparemos de três passagens úteis para esse estudo: o convívio com o tio, o escritor Antônio Salles, na Pensão Moss, no Rio de Janeiro; o relato de leitura de $O$ Primo Basílio e, por fim, a lembrança dos dormitórios do Internato do Colégio Pedro II. No segundo, os paratextos desempenharão papel preponderante: a capa de Baú de Ossos e as epígrafes iniciais do volume servirão a essa finalidade.

Não se pretende ignorar que ao dizer, o texto faz (e vice-versa), ou seja, não se pretende ignorar as limitações destas categorias. Desse modo, tal distinção aplica-se, para nossos propósitos, menos ao objeto do que, mais propriamente, ao ponto de vista adotado pelo observador em função do recorte priorizado.

\section{DESENVOLVIMENTO}

\section{I. $\quad$ O que o texto diz}

A certa altura de Baú de Ossos, referindo-se à sua "gente paterna", o narrador refere-se aos "grandes ledores que eram meu Pai, tio Salles, tio Júlio, minhas tias Alice e Candoca" (NAVA, 1999, p. 337). Envolto, como diz, por "grandes ledores", Nava desde cedo viu-se às voltas com os livros, enquanto objeto, e com a leitura, enquanto prática. Nesse domínio, um dos parentes citados pelo narrador adquire especial relevo. Nas palavras de André Botelho,

cumpre destacar a importância, nesse processo de educação sentimental e intelectual do narrador das Memórias de Pedro Nava, da educação propriamente literária. Lendo compulsivamente tudo o que lhe caía nas mãos desde os tempos do Anglo, foi por meio de Antônio Salles, grande 
homem da literatura cearense, porém, que sua formação acabou se definindo. (BOTELHO, 2012, n.p.)

De fato, a importância de tio Salles é decisiva e se verifica em diversas frentes e momentos. Casado com Alice Nava, irmã do pai do memorialista, José Nava, o escritor cearense privou da companhia do sobrinho, especialmente, entre os anos de 1916 e 1917. Nesse período, quando o adolescente tinha apenas 13 anos, os três dividiram o mesmo cômodo na Pensão Moss, enquanto Nava estudava no Internato do Colégio D. Pedro II, tradicional colégio da capital carioca.

Nesse período, Nava testemunhará, na figura de Antônio Salles, um claro exemplo do imbricamento entre leitura e escrita, traduzido em cotidiano familiar. No dormitório, o então adolescente literalmente dorme com os livros, num cômodo com cama dobrável que, durante o dia, virava o escritório de trabalho do tio, com direito a paredes ostentando os retratos dos pais, da esposa e dos dois escritores a quem o parente devotava especial admiração, Machado de Assis e Charles Dickens. Mas são "as seis estantes chegando quase ao teto, suas tábuas vergando ao peso daquele mundo de livros", que causam especial comoção no sobrinho: "Nunca eu tinha visto tanto livro como na biblioteca do meu tio" (NAVA, 2000, p. 207).

No microcosmo dos "grandes ledores" de sua "gente paterna", Antônio Salles chama a atenção não apenas pela volumosa biblioteca, de proporções até então inéditas na vida do jovem estudante, mas também porque, além de leitor, o tio era também escritor. Mais especificamente, o parente trabalhava como funcionário público do Tesouro, mas também desenvolvia o ofício de romancista, poeta, colunista e tradutor. Joaquim Aguiar resume, em Espaços da Memória, a rotina de Salles no Rio, observando que ele "acordava cedo, escrevia até às dez" e, após o almoço e a sesta, eventualmente voltava à escrivaninha (1998, p. 60). Naquele dormitório, com as estantes, ao fundo, "vergando ao peso" dos livros, Nava terá, muito provavelmente, testemunhado cenas como a que descreve, no volume anterior, quando da visita do tio à casa da família, em Juiz de Fora. Ali, vemos Salles entregue, desde cedo, à "luta mais vã", na lapidar definição drummondiana do trabalho com as palavras:

Todas as manhãs ele sentava-se cedo a essa mesa e escrevia até as dez, onze horas. Riscava, corrigia, lia baixo, rasgava, recomeçava; relia, rasgava outra vez, tornava a principiar, lia alto, retomava, até engastar o fecho de ouro na ourivesaria difícil do soneto ou do poema. Aí ele respirava aliviado, deixava cair a lima, o camartelo, o cinzel e acendia meio charuto. (NAVA, 1999, p. 318) 
A cena, em que não passa despercebida uma sutil e afetuosa ironia ao pendor parnasiano dos versos do parente (e que, de resto, ilustra uma das inúmeras citações indiretas a obras literárias diversas, no caso a "Profíssão de Fé" bilaquiana), permite vislumbrar, muito claramente, o modo como escrita e leitura se confundiam naquele cômodo, misto de dormitório, escritório e biblioteca. Debruçado sobre a mesa, escrevendo, tendo por fundo as estantes abarrotadas de livros, lidos, relidos ou por ler, o escritor compunha um cenário, aos olhos do futuro memorialista, que parecia traduzir visualmente, de maneira sensível, as palavras de Michel Schneider a propósito dessa escrita que é, também, leitura: "a literatura é sempre de segundo grau [...] em relação a ela mesma" (1990, p. 63).

Ainda no domínio do que o texto diz, as Memórias de Pedro Nava permitem vislumbrar a íntima relação entre escrita e leitura também em outro nível. Leitor voraz, desde muito cedo Nava acumulou leituras as mais variadas, algumas delas rememoradas, como seria natural, nos diferentes volumes do ciclo memorialístico. Chama a atenção, contudo, o grau de minúcia na reconstituição dessas leituras, cujo registro não se limita à mera catalogação de obras e autores lidos, mas abrange o modo próprio como aqueles textos ganhavam vida, muito pessoalmente, no imaginário do jovem leitor. A certa altura de Baú de Ossos, ao relembrar a leitura de $O$ Primo Basílio, o narrador oferece um bom exemplo dessa espécie de apropriação singular, aplicada, nesse caso, ao clássico de Eça de Queirós:

A casa, derrubada, persiste intacta dentro de mim e ainda mais reforçada pela presença de novos moradores. O engenheiro Jorge Carvalho, sua mulher, Luísa, sua criada Juliana, d. Felicidade e o conselheiro Acácio. Porque quando li O primo Basílio coloquei a ficção queirosiana na rua Direita 142 e jamais pude escapar desse sortilégio nas releituras. As salas se adaptavam perfeitamente à descrição do livro e os desabafos de Jorge com o Sebastião eram no escritório de meu Pai; d. Felicidade, o conselheiro, Julião e o Ernestinho tomavam chá na nossa sala de jantar, na nossa louça, Juliana recebia as cartazinhas no alto de nossa escada. Luísa morreu no quarto de minha Mãe. (NAVA, 1999, p. 226-227)

O trecho ilustra, com perfeição, aquilo que Pierre Bayard chama "atividades de complemento" (apud LANGLADE, 2013, p. 35), inerentes à leitura literária: não podendo dizer tudo e, por isso mesmo, caracterizada por seu "inacabamento", a obra "só pode realmente existir quando o leitor lhe empresta elementos de seu universo pessoal: elementos de cenário, paisagens, traços físicos e de caráter dos personagens etc.” (LANGLADE, 2013, p. 35) Associando a casa em que viviam Luísa, Jorge e Juliana àquela de sua primeira infância, Nava "complementa" os vazios do texto de Queirós, cuja descrição, embora pudesse remeter, por 
semelhança, ao espaço autobiográfico da rua Direita, evidentemente não poderia corresponder a ele integralmente.

Aplicada ao espaço romanesco, no exemplo acima, o fenômeno expande-se, é claro, para as demais categorias do texto ficcional. A propósito, Pierre Bayard considera que "esse trabalho de acabamento e de singularização é especialmente aparente para as personagens. A partir de minúsculos detalhes, regiões inteiras da vida de um personagem podem ser “completadas"' (LANGLADE, 2013, p. 35). Nesse particular, as Memórias oferecerão, uma vez mais, um bom exemplo do que afirma o crítico francês: ainda no volume inicial do ciclo, Baú de Ossos, Nava refere-se, de passagem, à leitura do livro de Henry Rider Haggard, aliás traduzido para o português, anos depois, pelo próprio Eça de Queirós: “Quando li As minas de Salomão dei à bela Fulata a figura gentil de Rosa - pele escura - em carne dura". (NAVA, 1999, p. 227) Como se vê, "traços físicos e de caráter dos personagens" ganham vida, no imaginário do leitor, a partir de associações biográficas, como a que Nava opera entre a "bela Fulata" e "a figura gentil de Rosa", empregada da avó paterna do protagonista, Inhá Luísa, no sítio de Juiz de Fora ${ }^{2}$.

Seja com Eça, em relação ao espaço, seja com Haggard, em relação aos personagens, o que está em jogo, em ambos os casos, é a presença do “texto 'singular' do leitor” (LANGLADE, 2013, p. 33), "trajeto de leitura que somente ele, talvez, mereceria ser chamado de texto e que é tecido pela combinação flutuante dos elos de minha vida com a trama dos enunciados combinados uma vez por todas pelo autor" (BELLEMIN NOËL apud LANGLADE, 2013, p. 32-33). Em outras palavras, todo e qualquer leitor, durante a leitura, também escreve um texto único (ou "singular"); disso, dão testemunho eloquente as Memórias ao referirem, por exemplo, os traços únicos, singulares, de $O$ Primo Basílio, obra ali concebida, por assim dizer, em coautoria de Pedro Nava e Eça de Queirós.

Se as considerações anteriores parecem incidir, mais claramente, sobre o que o texto diz, as seguintes já pedirão do observador, igualmente, alguma atenção ao que o texto faz. E,

\footnotetext{
${ }^{2}$ Ainda no nível das personagens, Nava irá referir, em Baú de Ossos, dois exemplos dessa interpenetração de vida e arte, escrita (a rigor, contação de histórias) e leitura (também a rigor, audição): ainda muito novo, ouvia de Rosa, antes de dormir, narrativas as mais variadas, a partir das quais fundava o seu universo ficcional já muito particular. É o que se lê, por exemplo, no trecho a seguir: "Além de ouvir a onda de poesia das histórias de Rosa eu as vivia porque alguns personagens de suas sagas andavam envultados em conhecidos de Juiz de Fora. Nosso primo Antonico Horta, por exemplo, com suas ameaças de virar criança pelo avesso, era certamente um bruxo." (NAVA, 1999, p. 228-229) Ocorrência semelhante, a referendar as considerações de Langlade e Bayard, também se verifica em trecho pouco posterior ao citado: "Gênio bom era o dr. Beauclair. Diziam que era médico e era mesmo, por sinal que médico de meu irmão Paulo. Instruído pelas histórias da Rosa, eu sabia, apesar de sua estatura, que ele era um dos sete anões da Branca de Neve". (NAVA, 1999, p. 230)
} 
se há pouco falávamos de uma espécie de leitor-autor, não será descabido enxergar, nos desdobramentos a seguir, uma outra figura, intimamente ligada à primeira: a do autor-leitor. Para esse fim, tomemos o excerto que se segue, no qual o narrador, recém-chegado ao Internato do Colégio Pedro II, no Rio, detém-se um momento sobre os colegas no dormitório:

Subitamente apagaram-se quase todas as lâmpadas e só ficaram acesos uns poucos globos azuis que espalharam no dormitório o bálsamo de uma claridade lunar. Os colegas começavam a dormir. Alguns afetavam um esboço comovedor de sorriso ao lábio; alguns a expressão desanimada dos falecidos, boca entreaberta, pálpebras entrecerradas, mostrando dentro a ternura embaciada da morte. Mas... com todos os diabos! Isto é Ateneu, não é meu, é Chácara da Mata e nós estamos em meio século dos depois ou mais, estamos no Campo de São Cristóvão... (NAVA, 2000, p. 309).

A intenção, como é claro, é assinalar a similaridade das experiências de Nava, no Pedro II, com as de Sérgio, n'O Ateneu. Antes dela, o memorialista já havia referido, no volume anterior, Baú de Ossos, como a vida parecia imitar a arte quando ele se punha a relembrar os personagens do romance, ironicamente equiparados a anjos (como, aliás, o próprio Raul Pompéia faz em seu livro): "Seus três coros de suas três hierarquias: seus Serafins, Querubins e Tronos; suas Dominações, Virtudes e Potestades; seus Principados, Anjos e Arcanjos - que eu iria encontrar iguais, iguais, iguais no Internato do Colégio Pedro ii." (NAVA, 1999, p. 54) Contudo, a passagem de Balão Cativo, isolada anteriormente, apresenta algo mais. Ela parece deliberadamente encenada, pois o lapso a que ela dá voz, como é evidente, seria facilmente corrigido pela simples exclusão do trecho alheio, devidamente silenciado. A decisão de transcrevê-lo, assim, tem o propósito de alçar a semelhança entre a experiência pessoal e a experiência do leitor a um outro nível, a saber, o de marca inscrita no texto. Em outras palavras, o trecho de Balão Cativo dramatiza o que o trecho de Baú de Ossos diz, transformando a repetição das trajetórias escolares dele próprio, Nava, e do protagonista d'O Ateneu, Sérgio, em fusão acidental (mas nem tanto, como estamos propondo) de narrativas.

Contudo, a passagem acaba por encenar, além da percepção de excepcional similitude entre o livro e a vida, outro fenômeno de ordem mais geral, aludido por Antoine Compagnon: “A citação, graças à confusão metonímica a que preside, é leitura e escrita, une o ato da leitura ao de escrita” (1996, p. 41). Ora, o que o excerto de Balão Cativo faz é precisamente encenar essa “confusão" (apresentada, sintomaticamente, como lapso), a união entre "o ato da leitura ao de escrita" por meio da citação - união surpreendida, na oportunidade, quase que em flagrante, em curso, como "ato" (um "ato falho", diríamos, ainda que fingido). Muito argutamente, Nava 
o fará por meio do uso de itálico, e não de aspas - detalhe que, aos olhos de Compagnon, não deixa de ser relevante. Com efeito, o crítico francês assim distingue o uso dos dois sinais gráficos:

Escrevo em itálico meu léxico íntimo, um dicionário poliglota ou idioletal, minha enciclopédia pessoal. Assim, estou mais presente no itálico que em qualquer outro lugar: o itálico é narcisista; desejaria, sem dúvida, que o leitor recortasse meu texto seguindo seu traçado. Em compensação, tento uma esquiva com as aspas, peço ao leitor que me conceda o benefício da dúvida. Digo-lhe: "Apanhe isso como você quiser, mas com pinças, não sou eu que devo ser apanhado" ou "Não gostaria de o dizer, mas, de qualquer modo, não posso agir de outra forma”. (COMPAGNON, 1996, p. 53-54)

A oposição entre o itálico, no qual o autor está "mais presente (...) que em qualquer outro lugar", e as aspas, através das quais se tenta "uma esquiva", encontra no trecho de Nava uma interessante formulação, sobretudo porque, ali, o conflito entre ambos os sinais gráficos (no que sugerem de distintas, mesmo contrárias, atitudes do narrador) dá-se enquanto disfarce de um em outro. Em outras palavras, o trecho em itálico descobre-se encobrindo, na verdade, mal dissimuladas aspas: a presença autoral descobre-se, enfim, renúncia involuntária. Ou, uma vez mais e com direito a um persuasivo jogo de cena: a escrita descobre-se leitura.

\section{O que o texto faz}

Logo no primeiro capítulo de seu trabalho, Antoine Compagnon, versando sobre leitura, escrita e citação, propõe uma relação entre elas e o modo como as crianças, ainda não alfabetizadas, ensaiam as mais rudimentares brincadeiras com o papel:

Antes ler, depois escrever: momentos de puro prazer preservado. Será que eu não preferiria recortar as páginas e colá-las num outro lugar, em desordem, misturando de qualquer jeito? Será que o sentido do que leio, do que escrevo tem uma real importância para mim? Ou não seria antes uma outra coisa que procuro e que me é, às vezes, proporcionada por acaso, por estas atividades: a alegria da bricolagem, o prazer nostálgico do jogo de criança? (COMPAGNON, 1996, p. 11-12)

O trecho esvazia, claramente, a dimensão intelectual do ato da leitura e da escrita, representada pelo discutível "sentido do que leio, do que escrevo", em favor de um interesse eventualmente mais imediato, mesmo manual, talvez inconsciente, e que tem a ver com a simples ação de recortar e colar, com "o prazer nostálgico do jogo de criança". Em apoio a sua 
tese, o crítico lembra que dois dos mais importantes escritores do século XX, James Joyce e Marcel Proust, tomavam o ofício de escrever em termos semelhantes: o primeiro, apresentando "a tesoura e a cola" como "gestos emblemáticos da escrita"; o segundo, evocando uma vez mais a tesoura ao comparar seu trabalho, "de bom grado", "ao do costureiro que constrói um vestido, mais do que ao do arquiteto ou do construtor de catedrais" (COMPAGNON, 1996, p. 12).

Em certa medida, Pedro Nava permite-nos vislumbrar as duas pontas desse paralelo: as Memórias nos dão notícia tanto do gosto pelo "jogo de criança”, referido por Compagnon, quanto de suas implicações para a obra do escritor maduro. No primeiro caso, o narrador revisita, em Baú de Ossos, o permanente estímulo à leitura que se respirava, como vimos há pouco, no tronco familiar paterno. É por meio da consulta a uma antiga carta escrita pelo pai, José Nava, que testemunhamos a presença, também aqui, do "prazer nostálgico do jogo de criança" evocado pelo crítico: "Não possuía noção de leitura e já minhas tias mandavam para Juiz de Fora revista infantil que eu folheava e cortava. Vejo isto numa carta escrita por meu Pai a 22 de fevereiro de 1908, agradecendo a remessa de publicação chamada Fafasinho." (NAVA, 1999, p. 353).

Tempos depois, encontramos Nava já adolescente, aos catorze anos, às voltas com a Antologia Nacional, volume que então circulava no Internato do Colégio Pedro II. Com a oferta abundante de autores da literatura portuguesa e brasileira, em prosa e verso, o menino acaba produzindo, inadvertidamente, poemas a rigor inéditos: "Toda aquela seleção de poesia lusobrasileira entrou de mim adentro como um aterro. Ficou decorada, mas sem ordem." A justaposição de versos advindos de poemas diferentes origina o que chama "sonetos Frankenstein", peças heteróclitas cujo estranhamento causava sensação "nos bailes de Belo Horizonte". O efeito, em grande medida cômico, não exclui um interesse de ordem estética, que já começava a chamar a atenção do jovem ginasial:

Eu tinha sacado aos poucos da memória uma peça de resistência, verso dum, verso doutro, metros diferentes, nenhum sentido, ausência de rimas, mas, curioso! guardando restos de beleza como os que ficam nos fragmentos martelados de pedra preciosa. (NAVA, 2001, p. 50)

Efetivamente, a prática da colagem interessará ao escritor maduro - e em mais de um sentido. No trabalho que dedica à obra do memorialista, Antônio Sérgio Bueno explora, por exemplo, a relação entre as muitas sugestões visuais presentes na face direita dos originais de Nava e o texto verbal, nem sempre contíguo à imagem, registrado na face direita. Valendo-se de metáfora sugerida pelo próprio autor, Bueno toma a escrita como "ponto crioscópico (ponto 
de solidificação dos líquidos) de um vasto material", ideia justificada "por ser o trabalho escritural o lugar de coagulação das impressões fluidas das memórias, além da harmonização dos traços de várias outras escritas." (1997, p. 132) Nesse contexto, as colagens, parte desse "vasto material", solidificam-se, por assim dizer, em texto verbal, como demonstra o crítico estabelecendo interessantes relações entre ilustrações dos originais de Balão Cativo, Chão de Ferro e $O$ Círio Perfeito e passagens marcantes desses volumes.

Contudo, como anunciamos logo de início, o foco desse estudo não abrange, exatamente, os bastidores da escrita naviana. Num domínio mais próximo de nosso recorte, Bueno também se debruça, ao examinar as colagens presentes no ciclo memorialístico, sobre as marcas textuais nas quais essa operação, que pressupõe a superposição e o deslocamento, mostra-se visível. É o caso de passagens, como lembra o crítico, nas quais se descobrem, disfarçadas no texto das Memórias, alusões a trechos de João do Rio, Mário de Andrade e Manuel Bandeira (1997, p. 132 e 133). Exemplos, aliás, do que afirmara pouco antes, dando conta de que a colagem, apesar de ser "um conceito oriundo das artes plásticas", "logo foi absorvido tanto pelo domínio verbal quanto pelo musical”. Daí que o processo comporte analogias com o que chama, a propósito de Nava, "escrita-sutura", cujas operações de transplante, como as citadas acima, conduzem à metáfora da cirurgia, à qual o próprio Compagnon nivelara, sob certo ângulo, o fenômeno da citação (BUENO, 1997, p. 132).

A colagem, porém, manifesta-se nas Memórias de Pedro Nava, de forma muito específica, em outro nível, mais imediatamente relacionado às artes plásticas, mas fundamental na composição do livro em sua composição material: referimo-nos à concepção das capas. Também artista plástico, Nava tomava parte ativa nesse processo, considerando-se, ao menos, as edições iniciais dos diferentes volumes das Memórias. Para Monique Le Moing, "seu gosto pela colagem, muito típico das suas influências modernistas, se exprime na sua colaboração estreita na concepção e na escolha das capas de suas obras" (1996, p. 155).

A breve descrição de algumas das capas de cuja idealização o memorialista participou, de fato, permite constatar a predileção de Nava por esse procedimento:

- Balão Cativo: Colagem do autor representando um balão seguro por laços dispostos como raios triunfantes.

- Chão de Ferro: partindo de uma colagem do autor, três camadas impressionantes: o céu ameaçador e plúmbeo, a montanha cor de ferro, o minério incandescente ... como no centro do mundo.

- Beira-Mar: também partindo de uma colagem do autor, a baía do Rio de Janeiro brilhando nos tons azuis do mar.

(...) 
- Galo das trevas: Partindo de novo de uma colagem do autor, sobre um fundo de igreja barroca o círio, o último círio... (LE MOING, 1996, p. 155)

O uso recorrente desse procedimento já anuncia, desde a capa, alguns movimentos típicos da citação, com a qual a colagem compartilha, como vimos, algumas similitudes. Dentre elas, figuram o deslocamento e a confusão de vozes (ou, mais estritamente no caso das artes plásticas, de sugestões imagéticas). É digno de nota que uma obra atravessada, em tantos níveis, pela interpenetração de leitura e escrita, fenômeno do qual a citação é manifestação eloquente, antecipe, por meio da colagem, mesmo antes do texto propriamente dito - ou, pelo menos, mesmo antes do que se costuma considerar, numa chave mais convencional, a voz propriamente autoral -, movimentos tão típicos do narrador. De certo modo, é como se a capa, também, fosse uma espécie de "página ao lado", como a chama Sussëkind, inspirando a feição do texto verbal. Ou como se, recuperando a sugestão de Bueno, estivéssemos diante, novamente, de um dado "ponto crioscópico", pelo qual as sugestões visuais da capa, ao menos enquanto gesto, também se coagulassem no "trabalho escritural" que se segue.

Também digno de nota, a propósito, é que essa confusão de vozes, tão típica da obra, comece a se insinuar já a partir dos "paratextos", essa espécie de "reforço ou acompanhamento", como lembra Gérard Genette, representado por um "certo número de produções, verbais ou não, como um nome de autor, um título, um prefácio, ilustrações, que nunca sabemos se devemos ou não considerar como parte dele", texto (2009, p. 9). Ou seja, essa confusão de vozes, de que a colagem representa uma manifestação visual, dá-se numa "zona indecisa", ainda segundo Genette, "entre o dentro e o fora, sem limite rigoroso, nem para o interior (o texto) nem para o exterior (o discurso do mundo sobre o texto)" (GENETTE, 2009, p. 10). De modo que, deslocada para a capa e, dado importante, por uma deliberação marcadamente autoral, a colagem agudiza essa tendência, já inerente ao paratexto, de confundir o dentro e o fora do texto, de embaçar o que, nele, constitui os limites do que é voz autoral ou rumor do mundo. ${ }^{3}$

\footnotetext{
${ }^{3}$ Reportagem da Tribuna de Minas, assinada por Mauro Morais, dá conta de um fato bem ilustrativo dessa "zona indecisa" representada pelo paratexto. Por conta dela, Matheus Nava, sobrinho-neto do escritor, relata que chegou a se indispor com Paulo Penido, sobrinho de Antonieta, esposa do memorialista, responsável até a data de seu falecimento, em 2016, pelos "direitos autorais de Pedro Nava”: "Cheguei a processar o Paulo, porque Pedro Nava era um escritor que gostava muito de colagens e não dá para aceitar livros com uma capa lisa. Na minha opinião, deveriam ser preservados da forma como foram feitos e pensados', comenta, referindo-se às recentes edições produzidas pela Companhia das Letras, cujo minimalismo das artes gráficas retoma as antigas pastas de arquivo produzidas nas cores pastéis de papel-cartão com nomes datilografados.” (MORAIS, 2018, on-line). A situação, como dissemos, remete à "zona indecisa" da qual a capa é exemplo: Matheus Nava parece compreendê-la como uma extensão da voz autoral e, como tal, a ser preservada, ao contrário do que se vinha praticando nas edições mais recentes, cujas concepções de capa corresponderiam a um critério, antes de mais nada, editorial.
} 
As epígrafes constituem, nas Memórias de Pedro Nava, um recurso de relevância ímpar. Elas se distribuem por todos os livros do ciclo, figurando, pois, em volume verdadeiramente exorbitante, uma vez que encimam, ao longo de suas milhares de páginas, a maior parte dos subcapítulos ${ }^{4}$. Contudo, a sua presença não se limitará a esse lócus textual: com efeito, elas figurarão mesmo antes, nas páginas iniciais dos diferentes tomos, ao lado de outras informações paratextuais. Dito isto, conclui-se que tais ocorrências não correspondem, inteiramente, ao que Gérard Genette compreende, "grosso modo", como tal:

Definirei grosso modo a epígrafe como uma citação colocada em exergo, em destaque, geralmente no início de obra ou de parte de obra: "em exergo", significa literalmente fora da obra, o que é uma coisa exagerada: no caso, o exergo é mais uma borda da obra, geralmente mais perto do texto, portanto depois da dedicatória, se houver uma. (GENETTE, 2009, p. 131)

Disseminadas por toda a vasta extensão das Memórias, as epígrafes, em Nava, não se comprazem com o uso corrente, "geralmente no início de obra ou de parte de obra". Essa ocorrência generalizada, como é claro, reforça a importância da citação, esse "recurso que faz com que a leitura ressoe na escrita" (COMPAGNON, 1996, p. 29), aspecto que estamos acompanhando em diversos níveis. Neste artigo, frente a esse corpus exuberante, operaremos um recorte modesto, mas de todo modo funcional para o objetivo de realçar, nesta altura da exposição, mais o que a obra $f a z$ do que a obra diz. Para esse fim, abordaremos aquelas epígrafes que acabam por corresponder, mais amplamente (embora não integralmente, como veremos em seguida), à definição "grosso modo" de Genette, ou seja, aquelas dispostas logo no início do livro (ou em seu "exergo", expressão que o estudioso considera algo excessiva). De fato, interessam-nos especialmente as páginas iniciais da obra, onde podemos flagrar os seus primeiros movimentos e onde, aparentemente, essa "zona indecisa" entre o dentro e o fora parece mais atuante.

Tome-se, por exemplo, o caso de Baú de Ossos, no qual esses movimentos iniciais têm, mesmo, algo de inaugural, uma vez que se dão no primeiro volume do ciclo. Ali, respectivamente, aparecem duas epígrafes: a primeira, de Manuel Bandeira, constitui a

\footnotetext{
${ }^{4}$ Exemplo dessa importância é a frequência com que a fortuna crítica de Nava se propõe a explorar esse aspecto da obra. Citem-se, a título de exemplo, os trabalhos de Monique Le Moing, que dedica um capítulo em separado para o estudo das epígrafes (1996. p. 106-120) e o de Maria do Carmo Savietto, cujo estudo do intertexto proustiano nas Memórias abrange, também, esse tipo específico de citação. (cf. Baú de Madeleines: o intertexto proustiano nas Memórias de Pedro Nava (2002)).
} 
transcrição integral do poema "Profundamente", a segunda, de Anatole France, constitui excerto do romance Le livre de mon ami.

O texto de Bandeira anuncia (e reverbera) o tema da ausência e, mais restritamente, da morte, ambos cruciais para a compreensão não só do volume inicial, no qual se leem os seus versos, mas também para o conjunto como um todo. Não por acaso, Davi Arrigucci Jr. associará o ciclo memorialístico ao tema do ubi sunt? (e o poema, sintomaticamente, repete a pergunta “Onde estão?" quase como um estribilho), bem como à forma poética da elegia, que "convém à prosa de Nava (...) tanto no sentido mais estrito de lamento por uma pessoa já morta, quanto no mais amplo, de estilo meditativo.” (1987, p. 93-94) Além disso, os versos aplicam-se, mais pontualmente, à dedicatória anterior, dirigida a amigos e familiares já falecidos e arrematada, justamente, pela expressão "Profundamente", cuja impressão, isolada e em letras espaçadas, confere maior solenidade à expressão. Curiosamente, num outro nível de manifestação suis generis, a epígrafe parece apontar, portanto, não só para o todo que se segue, como ocorre "grosso modo", segundo lembra Genette, mas também, local e retrospectivamente (considerando-se o sentido da leitura), para a dedicatória.

Anatole, por seu turno, faz o elogio do teor divinatório da descoberta do passado que, embora tomado usualmente como inferior ao dom sobrenatural de antever o futuro, parece-lhe mesmo preferível a este último ${ }^{5}$ : como facilmente se deduz, aqui estamos diante de uma citação que claramente se projeta, uma vez mais, não só para o restante de Baú de Ossos, mas para todo o ciclo, no qual é frequente o verdadeiro efeito de revelação assumido pela escavação do passado, seja pela viva recriação ficcional de espaços e personagens "há muito coisa mineral dos cemitérios" (NAVA, 1999, p. 9), seja pelo apuro de pesquisa capaz de recobrir informações e pontos de vista até então ignorados (como o é, de resto, o próprio futuro), ou seja ainda, por fim, pelo ingrediente verdadeiramente epifânico da memória involuntária, muito afim à madeleine proustiana, cuja irrupção gratuita e mesmo violenta de um passado, acordado por um objeto inocente qualquer (como um bolinho, para Proust, ou o relógio do pai, para Nava), revela uma potência francamente divinatória, por assim dizer.

Ainda que apenas as duas epígrafes acima mencionadas habitem, a rigor, o exergo do volume, vale a pena abordar, mesmo que brevemente, também a que se segue a ambas, já encimando o primeiro subcapítulo de Baú de Ossos. Trata-se de um trecho de carta enviada, por Eça de Queirós, a João Chagas (“Eu sou um pobre homem da Póvoa do Varzim...”), à qual

\footnotetext{
5 “Ainsi, il me parait, en ce moment, que la mémoire est une faculté merveilleuse et que le don de faire apparaitre le passé est aussi étonnant et bien meilleur que le don de voir l'avenir."
} 
se segue a primeira frase do livro, uma paráfrase daquela de Eça: "Eu sou um pobre homem do Caminho Novo das Minas dos Matos Gerais". A exemplo do que se verifica, mais comumente, nas epígrafes do exergo, cujo sentido costuma se projetar para o livro todo, também aqui estamos diante do mesmo fenômeno, como nos casos de Anatole e Bandeira. Afinal de contas, consistindo numa declaração de identidade (a epígrafe começa com a fórmula clássica "Eu sou..."), o seu teor resume o que se espera de uma obra memorialística, a saber, a escavação de um eu compreendido como parte de uma dada coletividade (GUSDORF, 1999)

Contudo, ainda que tais considerações, de ordem temática, sejam dignas de registro, é verificando como a capa e as epígrafes atuam em bloco, como conjunto paratextual, que poderemos vislumbrar, mais precisamente, o que a obra $f a z$ em termos de articulação entre leitura e escrita, desde os seus primeiros momentos. De fato, é nesse "acompanhamento" do texto, como o define Genette (não sem ressalvas, é verdade), que se constrói, muito precocemente, um efeito de protelação e diluição da voz autoral que, a nosso ver, antecipa um dos traços distintivos do ciclo.

Os paratextos de Baú de Ossos, assim, oferecem o seguinte panorama: desde logo, na capa, apresenta-se uma colagem, "Montanhas", com a qual, como lembra Barros e Salgado, "Pedro Nava já dá indícios de que tratará de muitos temas desenvolvidos em Minas Gerais"6 (2011, p. 76); a ela, seguem-se três epígrafes, das quais duas, a de Bandeira e a de Eça, serão objeto de paráfrase por parte do autor, na dedicatória e nas palavras iniciais do primeiro capítulo, "Setentrião". Ora, a colagem, as epígrafes e as paráfrases apresentam um dado em comum: são todas formas de citação, dispositivos de "renúncia" da própria voz, como observa Compagnon, em favor de um terceiro. Em suma: o leitor nem concluiu a leitura da primeira frase da obra e já tem, diante de si, uma colagem, três epígrafes e duas paráfrases - três manifestações de interpenetração entre escrita e leitura, fenômeno que, como vimos, atravessa o ciclo em toda a sua larga extensão. Nesse sentido, é mesmo muito simbólico que, logo na primeira frase do capítulo de abertura, quando se espera, enfim, que a voz autoral se faça ouvir mais distintamente, vencidos os variados e numerosos paratextos, estejamos diante de uma paráfrase que, praticamente, repete o que se acabou de ler na carta de Eça, de modo a embaçar, uma vez mais, os limites dentre o dentro e o fora (tão típicos, como lembra Genette, da zona paratextual), entre o próprio e o alheio. Trata-se de um descolamento (e de um deslocamento), portanto, ainda muito discreto, mesmo precário, em relação à voz de um terceiro, num

\footnotetext{
${ }^{6}$ Considero, para fins de exame da capa, a primeira edição de Baú de Ossos, tal qual Barros e Salgado.
} 
movimento anunciatório dessa escrita que, para retomar a proposição de Compagnon referida no início deste artigo, confunde-se, em grande parte, com a leitura.

\section{CONCLUSÃO}

Chegados à conclusão deste texto, convém recorrer, uma última vez, a Antoine Compagnon. A certa altura de seu trabalho, o crítico sublinha a associação da citação com o movimento, valendo-se, inclusive, das sugestões etimológicas da palavra:

(...) a substância da citação, para além dos acidentes do sentido e do fenômeno, é uma dynamis, um poder, a etimologia o confirma. Citare, em latim, é pôr em movimento, fazer passar do repouso à ação. (...) No vocabulário da corrida, diz-se que o torero 'cita' o touro: provoca seu ataque à distância, atiça-o agitando um embuste diante dos seus olhos. Esse é, certamente, o emprego que permanece mais fiel ao sentido primeiro e essencial da citação. Toda citação no discurso procede ainda desse princípio e conserva seu peso etimológico: é um embuste e uma força motriz, seu sentido está no acidente ou no choque." (COMPAGNON, 1996, p. 60)

Como acompanhamos há pouco, também o bloco paratextual de Baú de Ossos, com a sua reiterada remissão a vozes outras, pode bem ser tomado como uma dynamis. "Para além dos acidentes do sentido", ou seja, para além daquilo que o texto diz, o concentrado movimento inicial do ciclo, consistindo numa protelação e diluição sistemáticas da voz autoral, em sugestões contínuas de confusão entre o dentro e o fora, entre o próprio e o alheio, parece disparar, num gesto fundante, capaz de fazer "passar do repouso à ação", o discurso, enfim, do narrador, que nunca deixará de remeter, sob variados graus e em diferentes formulações, às sugestões híbridas de origem.

Neste nível, portanto, o que o texto $f a z$ alcança, naturalmente, o que o texto diz. Em outras palavras, respondendo ao gesto inicial dos paratextos, a obra também conta sobre aquilo que, desde o início, ela faz: seja nas experiências da remota juventude, lendo Eça; seja testemunhando, com o tio, o quanto as duas operações se retroalimentam ou, por fim, seja lembrando o quanto a escrita da experiência escolar se confunde com a leitura de um clássico literário da vida em internato - em todos esses episódios, enfim, o esgarçamento dos limites entre a leitura e a escrita encontra-se, na obra peculiar de Pedro Nava, como a ecoar o adágio popular (uma forma cristalizada de citação, a propósito), dito e feito. 


\section{REFERÊNCIAS}

AGUIAR, Joaquim. Espaços da Memória: uma leitura de Pedro Nava. São Paulo:

Edusp/FAPESP: 1998.

ARRIGUCCI Jr., Davi. Enigma e Comentário: ensaios sobre literatura e experiência. São Paulo: Companhia das Letras, 1987.

BOTELHO, André. "Balão Cativo: o aprendizado da memória”. Balão Cativo. São Paulo: Companhia das Letras, 2012. E-book.

BUENO, Antônio Sérgio. Vísceras da Memória: uma leitura da obra de Pedro Nava. Belo Horizonte: Editora UFMG, 1997.

COMPAGNON, Antoine. O trabalho da citação. Belo Horizonte: Editora da UFMG, 1996. GENETTE, Gérard. Paratextos Editoriais. Trad. Álvaro Faleiros. Cotia, SP: Ateliê Editorial, 2009.

GUSDORF, Georges. Les écritures du moi (lignes de vie 1). Paris: Editions Odile Jacob, 1991.

LANGLADE, Gérard. "O sujeito leitor, autor da singularidade da obra". Leitura Subjetiva e Ensino de Literatura. São Paulo: Alameda Editorial, 2013.

LE MOING, Monique. A Solidão Povoada: uma biografia de Pedro Nava. Rio de Janeiro: Nova Fronteira, 1996.

MORAIS, Mauro. Sobrinho-neto de Pedro Nava resgata objetos pessoais, fotos e vídeos do escritor. Tribuna de Minas, 26 jun. 2018. Disponível em:

https://tribunademinas.com.br/noticias/cultura/26-06-2018/sobrinho-neto-de-pedro-nava-falasobre-mega-exposicao-do-escritor-em-2019.html. Acesso em: 10 dez. 2020.

NAVA, Pedro. Baú de Ossos. São Paulo: Ateliê Editorial/Ed. Giordano, 1999.

NAVA, Pedro. Balão Cativo. São Paulo: Ateliê Editorial/Ed. Giordano, 2000.

NAVA, Pedro. Chão de Ferro. São Paulo: Ateliê Editorial/ Ed. Giordano, 2001.

NAVA, Pedro. Cadernos 1 e 2. São Paulo: Ateliê Editorial/Ed. Giordano, 1999.

SALGADO, Ilma de Castro Barros e. "O domicílio e a consignação do arquivo de Pedro Nava". Verbo de Minas: Letras. Juiz de Fora, v. 11, n. 19, p. 73-85, 2011.

SAVIETTO, Maria do Carmo. Baú de Madeleines: o intertexto proustiano nas Memórias de Pedro Nava. São Paulo: Nankin Editorial, 2002.

SCHNEIDER, Michel. Ladrões de palavras: ensaio sobre o plágio, a psicanálise e o pensamento. Trad. Luiz Fernando P. N. Franco. Campinas: Editora da UNICAMP, 1990.

SUSSËKIND, Flora. “A página do lado”. Papéis Colados. Rio de Janeiro: UFRJ, 1993. 
VASCONCELOS, Eliane. "De bissexto a contumaz: o arquivo pessoal de Pedro Nava". Inventário do Arquivo Pedro Nava. Rio de Janeiro: Edições Casa de Rui Barbosa, 2001.

Recebido em: 11 de dezembro de 2020 Aceito em: 13 de dezembro de 2020 